\title{
Chorioangioma with fetal anemia and polyhydramnios: a case report
}

\section{Rimmi Mahajan*, Ripan Bala, Madhu Nagpal}

Department of Gynaecology, Sri Guru Ram Das Institute of Medical Sciences and Research, Vallah, Sri Amritsar, Punjab, India

Received: 04 November 2016

Accepted: 30 November 2016

\section{*Correspondence:}

Dr. Rimmi Mahajan,

E-mail: mahajanrimmi9@gmail.com

Copyright: ( ) the author(s), publisher and licensee Medip Academy. This is an open-access article distributed under the terms of the Creative Commons Attribution Non-Commercial License, which permits unrestricted non-commercial use, distribution, and reproduction in any medium, provided the original work is properly cited.

\section{ABSTRACT}

Chorioangioma is a rare benign vascular tumor of the placenta. Although commonly symptomless, larger tumors may cause serious maternal and fetal complications. We present a case of chorioangioma which was diagnosed as an incidental finding on ultrasound in third trimester and referred to us for management. Color Doppler signified fetal anemia as depicted by hyperdynamic middle cerebral artery flow. Elective casarean section was done and a healthy baby delivered without any adverse outcome.

Keywords: Case report, Chorioangioma, Fetal anemia, Polyhydramnios

\section{INTRODUCTION}

Chorioangioma is the most common benign growth of the placenta. ${ }^{1}$ It is an angioma that arises from the chorionic tissue. Small lesions are usually minimally vascular, asymptomatic and not an uncommon finding during pathological examinations of the placenta. However, larger symptomatic lesions may present as polyhydramnios, nonimmune hydrops, fetal cardiomegaly, growth restriction and preterm labor. The tumors are readily diagnosed with gray-scale and color flow ultrasonography during an antenatal visit. ${ }^{2}$

\section{CASE REPORT}

MK, 26 year old gravida 2 abortion 1, with a chief complaint of amenorrhea for $81 / 2$ months, with her last menstrual period on 13 August, 2015 was referred to SGRDIMSR, after being diagnosed with chorioangioma at 33 weeks of gestation on ultrasound by private practitioner. She was subsequently admitted for safe confinement. Apart from this incidental finding, her pregnancy was uneventful. She was otherwise asymptomatic.

\section{Ultrasound findings}

Antenatal record revealed appropriate for age fetus with normal growth profile and matched gestational age. Earlier scans were normal and placental tumour was identified in scan dated 5/04/2016.

- Single live fetus corresponding to 32.2 weeks, cephalic

- Placenta fundo posterior with grade 2 maturity with a well-defined hypoechoic mass measuring $82 \times 65$ $\mathrm{mm}$

- $\quad$ AFI - 25

- E.D.O.D. 19/5/2016

06/04/2016 ( $2^{\text {nd }}$ opinion scan)

- $\quad$ Single live fetus 33 weeks

- Placenta fundo posterior with a hypoechoic mass measuring $76 \times 62 \times 84 \mathrm{~mm}$

- $\quad$ Single loop of cord around neck

- AFI - 25

- Doppler studies were not performed by the sonologist 


\section{Examination}

General physical examination and systemic examination was unremarkable.

\section{$\mathrm{P} / \mathrm{A}$}

Abdominal examination showed a fundal height consistent with 34-36 weeks of pregnancy with a longitudinal lie, cephalic, free floating head. Fetal heart sounds were present.

\section{Investigations}

- Hemoglobin $10.1 \mathrm{gm} \%$

- Bleeding Time 2 min $10 \mathrm{sec}$

- Clotting Time 5 min $15 \mathrm{sec}$

- Prothrombin Time $15 \mathrm{sec}$

- $\quad$ INR 1.07

- $\quad \mathrm{FT}_{4} 0.86 \mathrm{ng} / \mathrm{dl}$

- $\quad \mathrm{FT}_{3} 2.14 \mathrm{pg} / \mathrm{dl}$

- $\quad$ TSH $0.606 \mathrm{mIU} / \mathrm{L}$

Ultrasound/Color Doppler (performed at SGRDIMSR) 19/04/2016

- $\quad$ Single live fetus, gestational age of 35 weeks 4 days, cephalic.

- $\quad$ BPD corresponding to 35 weeks 4 days.

- $\mathrm{HC}$ corresponding to 35 weeks 3 days.

- AC corresponding to 35 weeks 5 days.

- FL corresponding to 35 weeks 4 days.

- Fetal heart rate is $140 \mathrm{bpm}$.

- Placenta fundo posterior and shows a well-defined hypoechoic mass measuring $7.3 \times 7.6 \mathrm{~cm}$ with increased vascularity on CFI.

- On power Doppler increased low resistive flow is noted, appearance raising possibility of chorioangioma.

- Liquor was on higher side with AFI of 23-24.

- Estimated fetal weight: 2736 +- 399 gms.

- E.D.O.D - 20/05/2016.

\section{Color Doppler}

- MCA: Shows hyperdynamic flow with increase in pulsatility index.

- $\quad$ S/D - 17.3 (hyperdynamic flow, with increased PI)

- $\quad$ PSV - $75.7 \mathrm{cms}$.

- $\quad \mathrm{ED}-4.3 \mathrm{cms}$.

- $\quad$ PI - 2.4 (increased).

- $\quad$ RI - 0.9

- Umbilical Artery shows normal color flow and spectral waveform.

- $\quad \mathrm{S} / \mathrm{D}$ - 2.2 (within normal limits) PI - 0.7 RI - 0.55

- There is no absence or reversal of diastolic flow seen.

- Right and left uterine arteries show normal color flow and spectral waveform.
- $\quad$ Right uterine artery S/D - 2.0 (within normal limits) PI - 0.7 RI - 0.5

- Left uterine artery S/D - 2.0 (within normal limits) PI - 0.7 RI - 0.5

- No persistent early diastolic notch seen.

- Fetal hyperdynamic flow is a sign of fetal anemia.

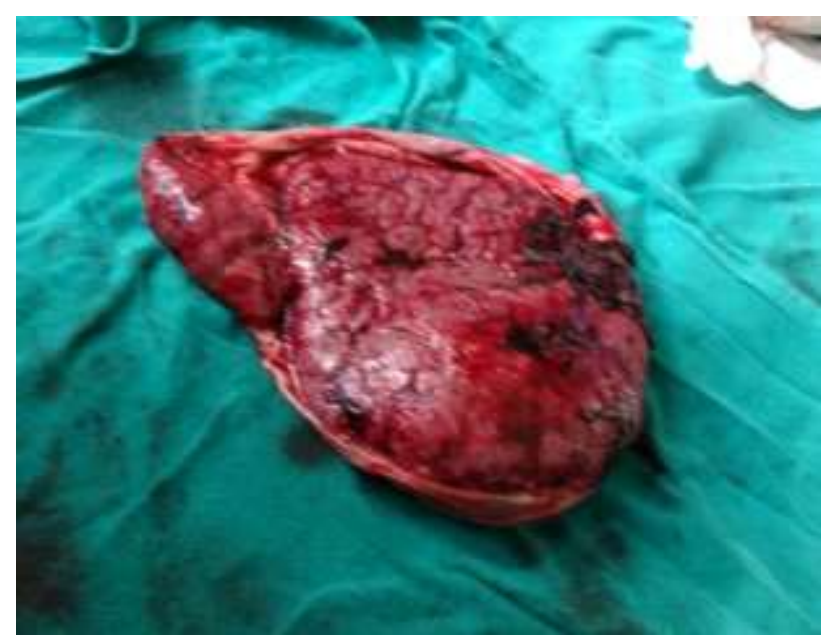

Figure 1: Surgical specimen showing ragged maternal surface, all lobes present and complete. Succenturiate lobe is present measuring $7 \times 7 \mathrm{~cm}$ in size, covered with membranes.

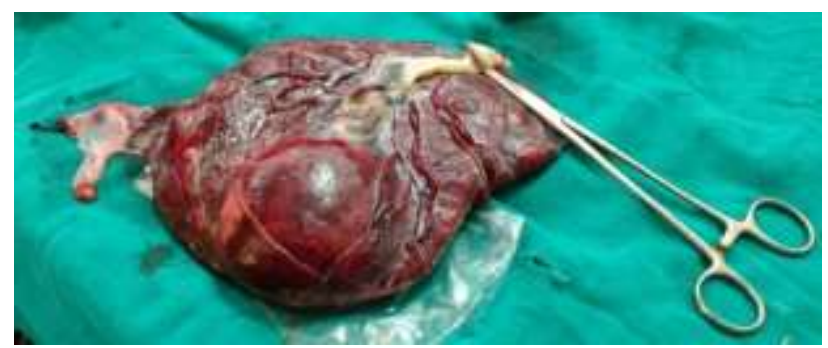

Figure 2: Surgical specimen showing smooth fetal surface, membranes intact. Cord insertion is eccentric, $10-12 \mathrm{~cm}$, and 3 vessels are present.

Chorioangioma can be seen with a circumference of $20 \mathrm{~cm}, 11 \times 11 \mathrm{~cm}$ in size, with a thickness of $4 \mathrm{~cm}$.

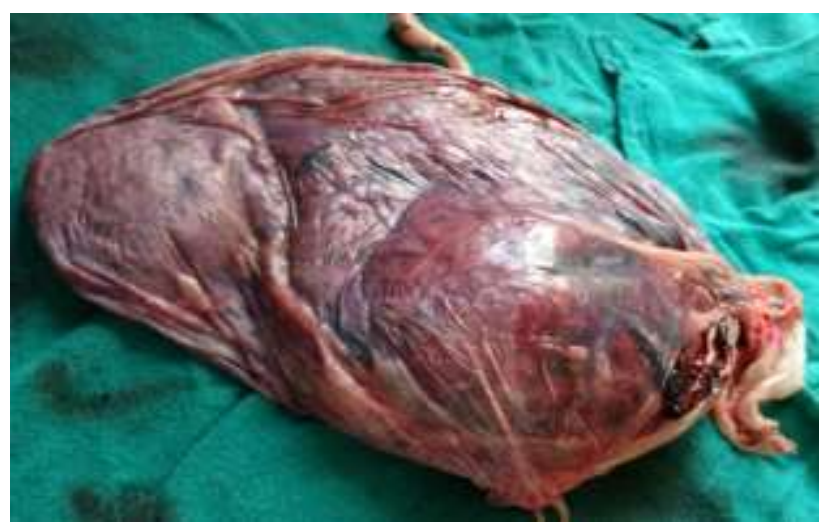

Figure 3: Surgical specimen showing the circumference of the placenta is $64 \mathrm{~cm}$ with a width of $1 \mathrm{~cm}$. 


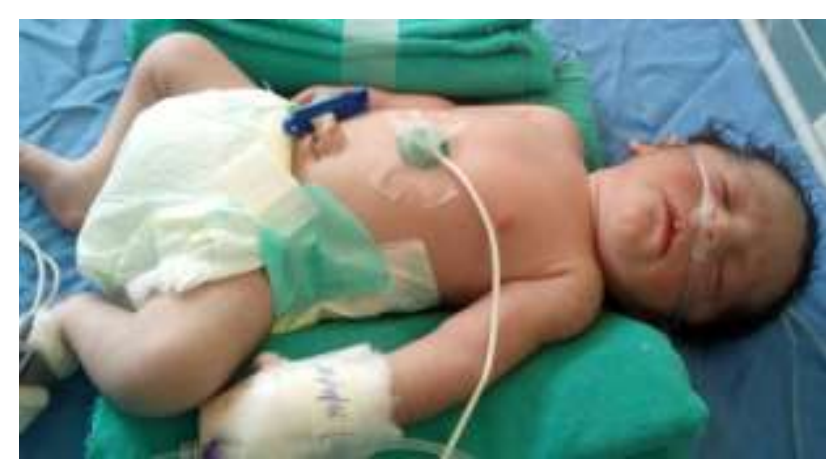

Figure 4: Healthy baby with birth weight of $2.6 \mathrm{~kg}$ was delivered by cesarean section.

Elective cesarian section was planned due to suspicion of fetal anemia. Packed cells of $\mathrm{O}$ negative blood were arranged prior to the procedure. Intraoperative period was uneventful. Placental separation was normal with complete expulsion spontaneously (Figure 1). Cord clamping was delayed by design. A healthy baby weighing $2.6 \mathrm{~kg}$ was delivered (Figure 2). Cord blood sampling after birth for neonate's hemoglobin was done which showed hemoglobin $17.0 \mathrm{gm} \%$. No blood transfusion was required. Neonatal period was uneventful requiring no intervention, however close observation was done for a period of 1 week.

\section{DISCUSSION}

Placental chorioangioma is the most common benign tumor of the placenta. ${ }^{3}$ The incidence in many series has been determined to be $<1 \% .^{4}$ It is a benign vascular tumor believed to arise from the primitive angioblastic chorionic tissue of the placenta. Tumor size of less than $50 \mathrm{~mm}$ is usually asymptomatic and unlikely to cause any adverse complications. ${ }^{5}$ A greater size is associated with numerous complications for the mother as well as the fetus. The adverse events are believed to be as a result of arteriovenous shunting resulting in a hyperdynamic circulation. The size of the tumor in our report was 76 $\mathrm{mm}$ on ultrasound and so did portend the advent of complications.

Antenatal ultrasound is essential for early diagnosis and close fetal monitoring for follow up. Ultrasound Grayscale generally shows a well-defined, complex, echogenic, rounded mass separate from the placenta located near the umbilical cord insertion site and protruding into the amniotic cavity. ${ }^{6}$ Doppler often demonstrates increased low resistance pulsatile flow within the hypoechoic areas which are actually large vascular channels. ${ }^{7}$ The patient was referred to us early on the basis of a tentative diagnosis on an antenatal ultrasound and so with regular follow up lead to a benign course and preferred, safe outcome.

Maternal complications include pregnancy induced hypertension, preterm labor, abruptio placentae, and polyhydramnios. The fetus may have growth restriction, cardiomegaly, thrombocytopenia, nonimmune hydrops, hemolytic anemia, and congestive heart failure due to a hyperdynamic circulation. A hyperdynamic circulation and polyhydramnios was present in this case and so decision making for day and route of delivery are extremely important. We were apprehensive of a neonatal emergency situation at the time of delivery.

The majority of tumors are asymptomatic and therefore expectant management is recommended in these cases. Careful follow up of smaller lesions with ultrasound is essential for early recognition and prevention of adverse events. Prognosis for small asymptomatic lesions is excellent, but is more guarded with larger sized tumors where complications such as fetal hydrops may be present. $^{8}$ Amniocentesis may be required for excessive polyhydramnios. ${ }^{9}$ Our patient was asymptomatic but since polyhydramnios was present and ultrasound signified a hyperdynamic circulation in the fetal MCA, elective cesarean section was preferred. Cord clamping was delayed due to suspected fetal anemia. $O$ negative blood was arranged for transfusion and kept ready in case cord sampling showed fetal anemia but was not needed. A healthy baby was delivered without complications.

\section{CONCLUSION}

A large chorioangioma is a risk factor for a variety of maternal and fetal complications. Antenatal ultrasound and Doppler are the investigations of choice for diagnosis. Adverse maternal outcome as well as fetal complications related to fetal anemia has to be kept in mind. There should be adequate preparation for blood transfusion on delivery, and staff alerted early for neonatal ICU admission, should the need arise. This case is a perfect example of the importance of regular follow up, timely confinement and intervention for an optimal outcome for both the baby and the mother.

Funding: No funding sources Conflict of interest: None declared

Ethical approval: Not required

\section{REFERENCES}

1. Faes T, Pecceu A, Van Calenbergh S, Moerman P. Chorangiocarcinoma of the placenta: a case report and clinical review. Placenta. 2012;33(8):658-61.

2. Abdalla N, Bachanek M, Trojanowski S, Cendrowski $\mathrm{K}$, Sawicki W. Placental tumor (chorioangioma) as a cause of polyhydramnios: a case report. International Journal of Women's Health. 2014;6:955-9.

3. Akercan F, Oncul Seyfettinoglu S, Zeybek B, Cirpan T. High-output cardiac failure in a fetus with thanatophoric dysplasia associated with large placental chorioangioma: case report. J Clin Ultrasound. 2012;40(4):231-3.

4. Sethi SK, Hemal U, Solanki RS, Bhagra A. Chorioangioma of placenta : A case report. Indian J Radiol Imaging. 2004;14:65-6. 
5. Hirata GI, Masaki DI, O'Toole M, Medearis AL, Platt LD. Color flow mapping and Doppler velocimetry in the diagnosis and management of a placental chorioangioma associated with nonimmune fetal hydrops. Obstet Gynecol. 1993;81(5(Pt 2)):8502.

6. Guschmann M, Henrich W, Entezami M, Dudenhausen JW. Chorioangioma - new insights into a well-known problem. I. Results of a clinical and morphological study of 136 cases. J Perinat Med. 2003;31(2):163-9.

7. Bashiri A, Furman B, Erez O, Wiznitzer A, Holcberg G, Mazor M. Twelve cases of placental chorioangioma. Pregnancy outcome and clinical significance. Arch Gynecol Obstet. 2002;266(1):535 .

Cite this article as: Mahajan R, Bala R, Nagpal M. Chorioangioma with fetal anemia and polyhydramnios: a case report. Int J Reprod Contracept Obstet Gynecol 2017;6:351-4. 